DOI: $10.52950 / E S .2021 .10 .1 .006$

\title{
MARKET CONCENTRATION IN THE PERSONAL COMPUTER INDUSTRY
}

\author{
IVANA NINCEVIC PASALIC, IVAN PAVIC
}

\begin{abstract}
:
The objective of this exploratory study was to investigate the present market concentration in the personal computer (PC) industry and compare it with the trends in other manufacturing industries. PC industry specific is that it operates on a global market. The results of the study show that the PC industry is increasingly concentrating. The market power of companies in the PC industry is growing due to merger and acquisition processes and the inability of some companies to maintain large economies of scale. Values of CR4 and HHI indicators for period from 2018-2020 indicate the oligopolistic structure of the PC market. However, due to technological innovations in PC and other competitive industries such as smartphone and tablet industries, PC vendors have less market power than manufacturers in other more stable oligopolistic industries. Moreover, comparison in concentration trends between the global PC industry and U.S. manufacturing industries points to differences in market concentration. Although the number of businesses in both industries is declining, market concentration trends differ as the PC industry shows a constant ascending trajectory of market concentration. Globalization processes that increase concentration and market power in industries characterized by large economies of scale are discussed as well, along with the results of the examination of relationships between market concentration rates and companies' financials.
\end{abstract}

\section{Keywords:}

Personal computer industry, market concentration, market power

JEL Classification: L10, L60, L63

\section{Authors:}

IVANA NINCEVIC PASALIC, Faculty of Economics, Business and Tourism, University of Split, Croatia, Email: ivana.nincevic.pasalic@efst.hr

IVAN PAVIC, Faculty of Economics, Business and Tourism, University of Split, Croatia, Email: pavic@efst.hr

\section{Citation:}

IVANA NINCEVIC PASALIC, IVAN PAVIC (2021). Market Concentration in the Personal Computer Industry. International Journal of Economic Sciences, Vol. X(1), pp. 84-99.,

10.52950/ES.2021.10.1.006 


\section{Introduction}

The personal computer (PC) industry has been one of the most dynamic parts of the electronics industry since the 1980s, affecting the rest of the computer industry and other industry sectors such as manufacturing, distribution, and logistics (Dedrick \& Kraemer, 2002). The personal computer industry is known for many innovations in its 40-year history (first PC launched in 1981 by IBM) and has revolutionized everyday life and business. Today, the PC industry presents one of the most global industries characterized by the large companies that manage their global production networks.

The modular nature of computers has made it possible to create an industrial structure characterized by a high degree of specialization and distribution of functions (Dedrick \& Kraemer, 2005). IBM standardized basic PC components in the 1980s that enabled modular assembly. Common standards, modular design, and easy PC assembly have made it possible to separate the production process into different parts, outsource production, and assemble products anywhere in the world (Carlson, 2006). This has led to a global division of labor and relocation of production to other continents (especially to Asia) intending to lower production costs and to be closer to the target market. Today, PC production is for the most part in Asia while assembly takes place closer to end customers in North America, Europe and Asia.

According to research by Chu (2013) in the period from 1995 to 2008, 48 PC manufacturers were selling approx. 250 computer brands with more than 1000 models on the market. Over the years, the profit margin of the industry has decreased from $4 \%$ to approx. $1 \%$ (Krabeepetcharat, 2012 in Marley \& Mooney, 2014) which has resulted in some companies no longer being able to achieve economies of scale and deciding on to leave the industry.

The descending number of publications in the Scopus database in the field of economics and business from 2000 onwards for "personal computer" is noteworthy in comparison to publications related to "mobile phones", indicating the repositioning of research trends. However, the PC industry presents an important part of the computer industry that lacks relevant and current research studies of its market structure. Therefore, this exploratory study aims to give an overview of today's PC industry, determine its market structure, vendors' market power and future research agenda. The following research questions (RQ) were formulated in this study:

RQ1: What is the market structure of the PC industry today? How is market power distributed between the vendors in the industry?

RQ2: What is the relationship between market concentration rates and vendors' financial data?

RQ3: Are there differences in market concentration in the PC industry in comparison to concentration trends in other industries?

The paper is organised as follows. Section 2 presents the conceptual basis of the paper by giving an overview of the PC industry. Section 3 outlines and discusses the market power and methodology of the exploratory study used to measure it. Section 4 presents the results of a study and Section 5 discusses the results, explains contributions to the research area and includes research limitations, and future research directions.

\section{Theoretical background: PC industry}

A personal computer is a "modular product whose components, peripherals, and software can be designed independently and integrated into the final system using standard technical interfaces" (Brusoni \& Principe, 2001 in Dedrick \& Kraemer, 2005). The aforementioned 
product modularity in the personal computer industry means a diversified supply chain. PC manufacturers export parts of their production so that they can concentrate on defending their competitive position by focusing on sales, product management, marketing activities, as well as on coordination of product development, distribution and customer support as working with external partners such as contract manufacturers $(C M)$, original design manufacturers (ODM), distributors and other service providers (Dedrick \& Kraemer, 2005).

Hundreds of companies have become involved in a global production network organized by the world's major PC vendors who are implementing gradual innovations relying mainly on (Dedrick \& Kraemer, 2005): 1) their product development partners - parts suppliers/manufacturers who make frequent changes to their products (higher processor speed, higher capacity, longer parts' life) and 2) Microsoft and Intel for new technologies because they control common interface standards today. Therefore, PC manufacturers supply the global market with standard product lines and in this way achieve economies of scale.

Den Hartigh et al. (2016) investigated the factors influencing the struggle of companies for market dominance in the early PC industry and identified the following factors: 1) technological factors (technological innovation, technical quality, modularity, substitute compatibility, complement compatibility, PC platform flexibility), 2) network (number of supply-side partners supporting the platform, network leader size, network diversity, management structure and 3) strategic factors including time of entry, product range, number of production facilities, number of distribution facilities, pricing policy, complementary product provision, reputation and financial support. The study of Özsomer \& Cavusgil (2000) showed that "negative interdependence i.e. full competition" prevailed after the emergence of technology standard, which happened after the technological legitimation phase.

Taking into account the specifics of the PC industry, the production of desktop computers and laptops (portable computers) will be considered as the same industry due to the high degree of interchangeability (of these two products) on the demand side, and the ability to use the same technological knowledge in making both. This approach is standard in analyses made by research organizations Gartner and International Data Corporation (IDC). Gartner shipment data that will be used in this study include desktop PCs, laptops, and ultra-mobile premiums, but exclude Chromebooks and iPads.

As the entire technology sector moved in a more software and service-oriented direction (e.g. Arora et al., 2001), the PC hardware market has been gradually shrinking since 2011, the year when it reached the highest level i.e. 365 million unit shipments (Gartner, 2020). Graph 1 shows the number of worldwide PC shipments to distributors and others in the supply chain, which shows a clear seven-year decline in shipments starting from 2012 to 2018 (Richter, 2019; Gartner, 2016-2021). According to the latest data, 2019 was the first year in which there has been an increase in the number of PC shipments. 


\section{Graph 1: Worldwide PC Vendor Unit Shipments per year (Gartner, 2016-2021)}

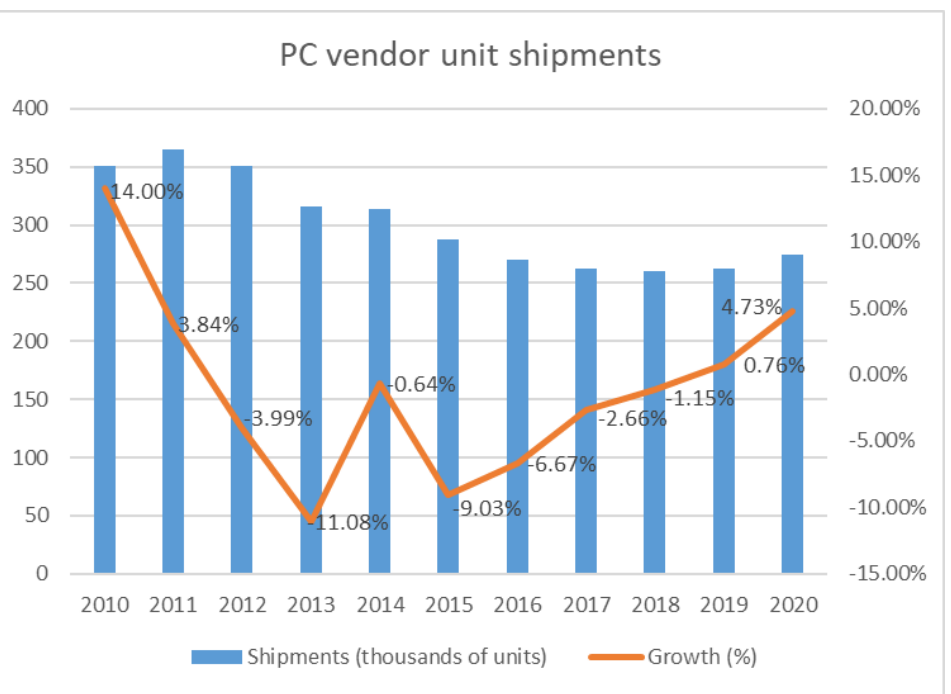

Technological advances, consumer market disposable income, as well as corporate spending cycles are driving factors for the demand in the PC market (First Research, 2020). The mentioned increase in shipments can be explained in necessary upgrades to Windows 10 as Microsoft has shut down support for Windows 7, causing that many business customers have been forced to upgrade and replace their PCs (Gartner, 2020).

According to research organizations Gartner and IDC, projections on the number of unit shipments in the future were slightly positive a year ago (before Covid-19 pandemics emerged) due to the announced innovations in the PC market in the form of 2-in-1 devices and other premium ultra-mobile devices. However, due to the Covid-19 pandemics, the results of the first quarter of 2020 indicated a new decline in shipments primarily due to events in China (Gartner, 2020b), however other quarters of 2020 showed the growth of PC shipments caused by strong demand in mobile PCs and recovery in supply chain disruptions (Gartner, 2020c \& Gartner, 2021).

Mazzucato (2002) summarized first 30 years of PC industry as turbulent, as characterized by high entry and exit rates, short company life-spans, radical innovation, and rapidly falling prices. This resulted in an industry with advanced technological competition (Bresnahan \& Greenstein, 1999). Personal computer industry is well known for mergers and acquisitions that occurred in its past, the following had a major impact on the industry:

- In 2002 HP (USA) merged with Compaq (USA),

- In 2005 IBM (USA) sold its PC division to Lenovo (China),

- In 2007 Acer (Taiwan) took over Gateway (USA) and in 2008 Packard Bell (USA),

- In 2011 Lenovo acquired Medion (Germany) and CCE (Brazil) in 2013.

The biggest turning point in the industry was Lenovo's acquisition of IBM's PC division in 2005, which happened for the reason that IBM, unlike Lenovo, no longer wanted to pursue a lowmargin and economies of scale strategy (Williams \& Kallender, 2004). This event significantly influenced the global balance of power of computer manufacturers, and presents the beginning of the increased domination of Asian countries, apart from American computer manufacturers. The mentioned acquisition has aroused the interest of many scientific studies because it is a pioneering case where an emerging market company buys a more technologically advanced competitor in a developed country (Yu, 2018). In a study of Chinese acquisitions, Deng (2009) proves that Chinese companies go abroad primarily to improve a 
company's critical competencies, as acquiring companies that have valuable resources creates an opportunity to become a globally competitive company.

\section{Market power and concentration}

Market power signifies the degree of control that companies have over the prices in an industry or market, i.e. the ability of companies to independently determine the price of products. Companies that can set a price above the marginal cost are companies that have a certain monopoly or market power (Pavić et al., 2016). Tipurić et al. (2003) define market power as the degree of control of one or a small number of firms over key decisions within the observed industry and point out that market concentration is a common measure of the market power of an industry.

Market power ranges from companies with no market power to companies that have significant market power, which corresponds to the direction of strengthening the market power that ranges from perfect competition, monopolistic competition, through oligopolies to monopoly. These market structures are defined based on the number of sellers, number of customers, the degree of product similarity, the availability of information, entry or exit market barriers, etc. Market structure shows the behavior of buyers and sellers in the market and the factors influencing this behavior, i.e. explains the magnitude of the power of buyers and sellers in different types of markets and their different behavior concerning differences in their power (Pavić, 2009). Therefore, except for companies in a market of perfect competition, other companies have a certain freedom in determining the prices, i.e. they enjoy greater or lesser market power.

\section{Methods used: market concentration indicators}

There are several measures whose purpose is to determine the degree of market concentration and are called market concentration indicators. The most used indicators are concentration ratio $(\mathrm{CR})$ and Herfindahl-Hirschman Index $(\mathrm{HHI})$ which will be presented in this section in more detail, and will be analysed in the subsequent section. Other concentration measures include Lerner index of Monopoly Power, Gini coefficient, Bain Index of Monopoly, and others.

The concentration ratio is represented by the sum of the market shares of several largest companies in the observed market, usually four, eight or twelve and it measures market power in the form of a percentage. The concentration ratio is measured by the following expression where $\mathrm{CR}_{n}$ denotes the market share of $n$ companies in the observed industry, and $S_{i}$ stands as the market share of the $i$-th company of the observed industry.

$$
C R_{n}=\sum_{i=1}^{n} S_{i}
$$

The value of the concentration ratio ranges from 0 to $100 \%$. The higher its value, the more concentrated the market is. If the value is 0 , it means that there is a large number of equal companies in the market. The value of $100 \%$ signifies a monopoly. A loose oligopoly means an industry in which the 4 largest companies produce 40 to $60 \%$ of the product and have moderate power, while a tight oligopoly signifies an industry in which the 4 largest companies have $60-80 \%$ of the market and have great market power.

There are some limitations to the application of the concentration ratio and special attention should be given to (Pavić, 2016): 1) the importance of the local market which should not be 
neglected in some industries as wrong conclusions can be drawn in regards to the level of market power, 2) the share of imported products in the national market, 3) the breadth of the definition of the product as CR is lower with higher data aggregation, and 4) the degree of inequality of market share of the largest companies in the industry as CR in different industries does not mean the same market power.

The Herfindahl-Hirschman Index $(\mathrm{HHI})$ eliminates some of the shortcomings of the concentration ratio by taking into account all firms in the industry or market. HHI shows market power as the sum of the squares of the market shares of all firms in an industry or market.

$$
H H I=\sum_{i=1}^{n} S_{i}^{2}
$$

The $\mathrm{HHI}$ ranges between 0 and 10,000. It approaches value of zero when there is a large number of market participants of relatively equal sizes whereas it reaches the maximum of 10,000 in the case of monopoly. An HHI index with a value of less than 800 indicates that firms have no or little market power, 800 to 1600 indicate low to moderate market power which is a feature of a loose oligopoly, a value between 1600 and 2400 indicates high market power of a firm (tight oligopoly), and values above 2400 indicate that there is a dominant company or industry of a monopolistic nature. Moreover, US Department of Justice consider markets in which $\mathrm{HHI}$ ranges between 1,500 and 2,500 to be moderately concentrated whereas highly concentrated markets are those that register $\mathrm{HH}$ indices higher than 2,500 (US Department of Justice \& FTC, 2010).

\section{PC market concentration - analysis and relations}

\subsection{Analysing the global PC shipments}

This section presents the results of data analysis based on the data of total global PC unit shipments that were used to calculate companies' market shares. The data used is publicly available and communicated on a quarterly basis by research organization Gartner. Data for the five years period from 2016 to 2020 has been considered, noting that the data for 2020 is preliminary according to Gartner. Figure 1 shows the market shares of the six largest PC manufacturers over five years period. According to Gartner (2021), the largest PC manufacturers as of 2020 are Lenovo (headquarter in Hong Kong, China), Hewlett-Packard (HP) (headquarter in Palo Alto, California, USA), Dell (headquarter in Round Rock, Texas, USA), Apple (headquarter Cupertino, California, USA), Acer (headquarter Taipei, Taiwan) and Asus (headquarter Taipei, Taiwan). 
Figure 1: PC vendors' market shares (\%) from 2016-2020

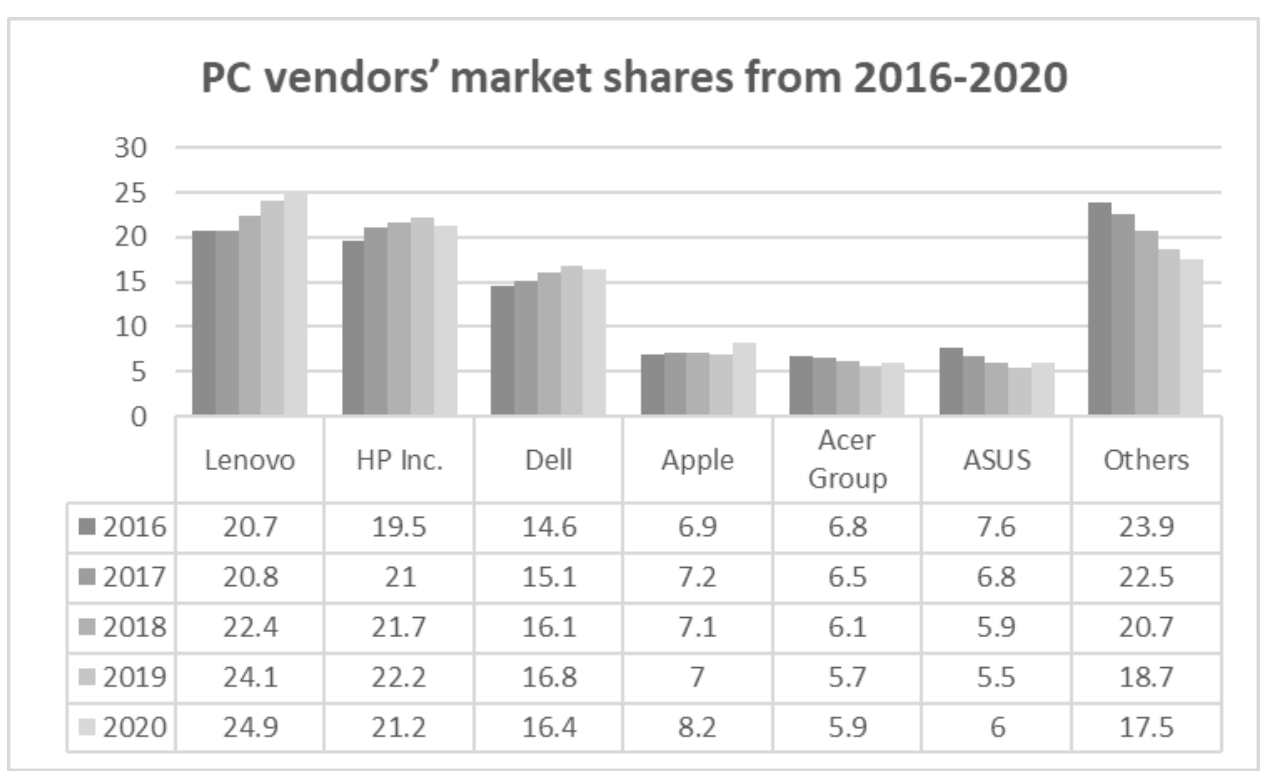

Source: Authors' presentation based on Gartner data (2017-2021)

The continuous increase in market share for Lenovo, HP and Dell can be seen over the years, up to 2019, a slight decline in shipments at Apple, a drop in the market position for Acer and Asus, and a 30\% decrease in the market share of "other companies". Preliminary 2020 data shows the continuation of increase of market share for Lenovo and HP, Dell faces slight decrease unlike years before, while Apple, Acer and Asus show increase in market share after few years of decline. Lenovo, as a global PC leader, is increasing its share in the highest percentage. The market shares of the six largest PC manufacturers increased from 2016 to 2020 by 6.5 percentage points (from $76.1 \%$ to $82.6 \%$ ) which confirms the conclusions of Marley \& Mooney (2014) and shows that the global PC manufacturer industry is increasingly concentrating.

Concertation ratio and Herfindahl-Hirschman index have been used to inspect the degree of PC industry concentration, as were the most convenient measures due to available PC shipment unit data. Moreover, the aforementioned concentration measures are the most commonly used measures of market concentration in the literature, regardless of the market and industry. For example, both indicators were used when examining the market competition level in the worldwide airline market (Yaşar \& Kiraci, 2017), the Russian banking sector (Stazhkova et al., 2017), and many other.

\section{Concentration ratio}

The calculated market shares enabled the determination of the market structure of the industry and the degree of market power of the company through the concentration ratio for the 4 largest companies. The concentration ratio of the largest four companies (CR4) shows a large increase over five-year period, from $58.9 \%$ in 2015 to $70.7 \%$ in 2020 . These changes in market concentration are the result of constant growth, primarily of Lenovo, then HP and Dell, while Apple, Asus and Acer were losing market share up to 2020, but last year this trend changed.

The obtained values of concentration ratios indicate a change in the level of market concentration that is the result of globalization - mergers and acquisitions of smaller companies. The CR4 indicator for 2019 and 2020 exceeds 70\% indicating the oligopolistic 
structure of the PC market. It implies the existence of a couple of dominant companies whose products are differentiated (they differ in model, processor power, size, color, packaging, service, etc.). Companies in the PC industry have the power to influence the price of products and non-price changes (promotion and marketing used as factors in increasing demand for products), but they can always expect reactions from their competitors. Given that the PC industry is characterized and determined by technological innovation, competition is high despite the relatively small number of dominant companies. Entry and exit processes are limited due to barriers such as high economy of scale required, high entry costs, and artificial barriers such as the strength of already established PC brands.

Six PC vendors previously mentioned are not the only ones with market power in the industry, as evident by the review of the US market data from 2018 (latest available data). The highest market share is held by domestic PC manufacturers HP and Dell (57\% together), followed by Lenovo, Apple and Microsoft (Gartner, 2019). The distribution of market shares and power is different compared to the global level. Moreover, Microsoft broke through to the fifth place in terms of market share, ahead of Acer and Asus. "Other" companies have a significantly lower percentage than at the global level, which leads to the conclusion that the US market is more concentrated than the global one, which confirms the existence of an oligopolistic market structure $\mathrm{CR} 4=85 \%$.

\section{Herfindahl-Hirschman index}

In order to confirm the concentration of the global PC market and its market structure, the $\mathrm{HHI}$ index was used, i.e. partial $\mathrm{HHI}$ because it was not possible to collect data for all PC industry companies, more precisely those with small market shares (similarly done by Naldi \& Flamini, 2014 for the mobile phone industry). This does not significantly affect the overall result as the index is constructed in such a way that the firms with a larger market share are given proportionally more weight. The results shown in Graph 2 show an increase in the index at the global level in the observed period from 2016-2020 and confirm a moderately concentrated market.

Table 1: HHI in global PC market 2016-2020

\begin{tabular}{ccccc} 
HHI 2016 & HHI 2017 & HHI 2018 & HHI 2019 & HHI 2020 \\
\hline 1173.51 & 1241.98 & 1354.29 & 1467.63 & 1476.46 \\
\hline
\end{tabular}

\subsection{Examination of relationship between market concentration rates and financial data}

This section presents the results of examining the relationship between market concentration ratio and companies' revenue and net income (profit). Correlation between CR2, revenue and net income of 2 largest vendors (Lenovo and HP) and correlation between CR4, revenue and net income of 4 largest vendors (Lenovo, HP, Dell and Apple) has been analysed using IBM SPSS Statistics 23.0. The data used was collected via Macrotrends (2021), and crosschecked with companies' annual financial statements for 2019 and 2020. Following Tables 2 and 3 present the results of the analysis where Pearson correlation has been calculated. 
Table 2: Overview of the correlation between CR4 and different financial measures for the period 2017-2020.

\begin{tabular}{l|ccc}
\multicolumn{1}{c}{ CR4 } & Revenue & Net income \\
\hline CR4 & 1 & $0.96^{*}$ & 0.719 \\
Revenue & $0.96^{*}$ & 1 & 0.872 \\
Net income & 0.719 & 0.872 & 1 \\
\hline
\end{tabular}

*correlation is significant at the 0.05 level

Table 3: Overview of the correlation between CR2 and different financial measures for the period 2017-2020.

\begin{tabular}{l|ccc}
\multicolumn{2}{c}{ CR2 } & Revenue & Net income \\
\hline CR2 & 1 & $0.985^{\star}$ & 0.156 \\
Revenue & $0.985^{\star}$ & 1 & 0.293 \\
Net income & 0.156 & 0.293 & 1 \\
\hline
\end{tabular}

*correlation is significant at the 0.05 level

The CR indicators show a strong correlation with the revenue for the observed period (see Table 2 and Table 3), which is presented by Pearson's correlation coefficient, which regardless of the scope (two largest or four largest PC vendors) exceeds 0.9 . When the recorded value of the Pearson coefficient is greater than 0.8 , in the economics literature it is defined as a strong correlation between the considered variables, and in this case it amounts 0.96 and 0.985. The correlation between CR indicators and net come is not statistically significant.

\subsection{Comparative overview of the PC industry with other industries}

The specificity of the PC industry is that it operates in a global market. As previously shown, the market power of companies in the PC industry in the world is growing due to the processes of mergers and acquisitions and the inability of some companies to maintain the economies of scale. When comparing the trends of a slightly wider industry, i.e. sector, the results differ. Observing the data for the computer sector of the U.S. manufacturing industry in Table 4 for 2012 and 2017, one can recognize the decreasing trend in the number of enterprises in the sector (code 334 ) by $3.2 \%$. Although data on the concentration ratio and the HerfindahlHirschman index (unit shipment based) have not yet been made public for 2017 on the website of the U.S. Bureau of Statistics (expected in late 2020 according to St. Thomas University), their low values indicate low market concentration and low firm power. The sector 334 represents a high degree of data aggregation (includes computer, audio, video, communication equipment, etc.), and lower values of CR4 confirm the theory that the CR value is inversely proportional to the data aggregation. Four companies in the industries under codes 3341 and 334111 have a higher CR than the sector (334), and this CR is $31.5 \%$ and $50.9 \%$ respectively. The electrical computer industry as the closest to the PC industry (albeit on a larger scale) shows the characteristics of an oligopoly. 
Table 4: Concentration data in computer sector and related industries in the U.S. economy

\begin{tabular}{|l|l|l|l|l|l|}
\hline $\begin{array}{l}\text { NAICS } \\
\text { code }\end{array}$ & Titles & $\begin{array}{l}\text { No. of businesses } \\
\mathbf{( 2 0 1 2 )}\end{array}$ & $\begin{array}{l}\text { No. of businesses } \\
\mathbf{( 2 0 1 7 )}\end{array}$ & $\begin{array}{l}\text { CR4 } \\
\mathbf{( 2 0 1 2 )}\end{array}$ & $\begin{array}{l}\text { HHI50 } \\
\mathbf{( 2 0 1 2 )}\end{array}$ \\
\hline 334 & $\begin{array}{l}\text { Computer and Electronic } \\
\text { Product Manufacturing }\end{array}$ & 11776 & 10730 & 10.8 & 71.5 \\
\hline 3341 & $\begin{array}{l}\text { Computer and Peripheral } \\
\text { Equipment Manufacturing }\end{array}$ & 1069 & 923 & 31.5 & 421.9 \\
\hline 334111 & $\begin{array}{l}\text { Electronic } \\
\text { Manufacturing Computer }\end{array}$ & 362 & 302 & 50.9 & 845.6 \\
\hline
\end{tabular}

Source: US Census Bureau, 2012 \& 2017

The production for 21 sectors has been analysed on the example of the U.S. manufacturing industry, where the average number of companies in 2017 was 12,037 (US Census Bureau, 2017), which is $12.5 \%$ fewer companies than in 2007 (Graph 2). However, the results for the concentration ratio show a slight increase, while the results of the Herfindahl-Hirschman index show a slight decrease in value from 2007 to 2012.

\section{Graph 2: Number of firms in the U.S. economy (US Census Bureau, 2007-2017)}

\section{Number of firms in all industries in US}

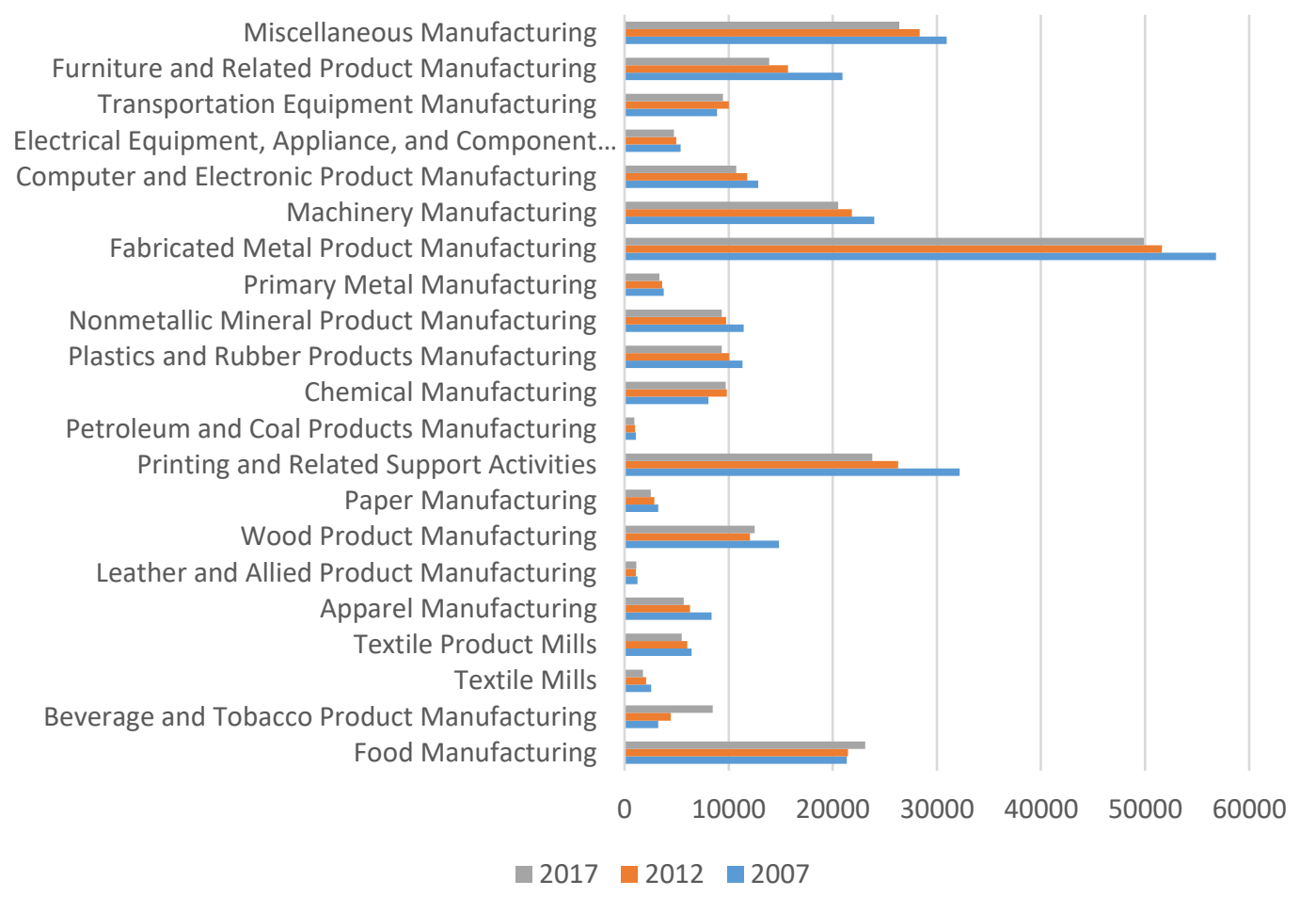

The trend of the U.S. manufacturing industry indicates a general decrease in the number of manufacturers, while there are no significant changes in market concentration (Table 5) and thus in the market power of companies, which could suggest that smaller companies are leaving the industry. This trend is different from one of the PC industry where the decline in the number of companies is accompanied by an increase in market concentration. 
Table 5: Concentration ratio (CR4) and $\mathrm{HHI}$ in the U.S. manufacturing sector

\begin{tabular}{|r|l|c|c|c|c|}
\hline \multicolumn{2}{|c|}{ Sector } & \multicolumn{2}{|c|}{ CR } & \multicolumn{2}{c|}{ HHI } \\
\hline $\begin{array}{c}\text { NAICS } \\
\text { code }\end{array}$ & \multicolumn{1}{|c|}{$\mathbf{2 0 0 7}$} & $\mathbf{2 0 1 2}$ & $\mathbf{2 0 0 7}$ & $\mathbf{2 0 1 2}$ \\
\hline 311 & Food Manufacturing & 14,8 & 16,3 & 102,1 & 110,7 \\
312 & Beverage and Tobacco Product Manufacturing & 39,1 & 41,3 & 555,4 & 578 \\
313 & Textile Mills & 19,6 & 20,6 & 160,2 & 158,1 \\
314 & Textile Product Mills & 32,8 & 24,8 & 418,6 & 272 \\
315 & Apparel Manufacturing & 7,9 & 10,3 & 44 & 54 \\
316 & Leather and Allied Product Manufacturing & 18,6 & 23 & 174,8 & 236,9 \\
321 & Wood Product Manufacturing & 9,1 & 9,2 & 38,3 & 42,6 \\
322 & Paper Manufacturing & 24,0 & 29,5 & 227,8 & 310,6 \\
323 & Printing and Related Support Activities & 13,5 & 15,3 & 77,9 & 95,4 \\
324 & Petroleum and Coal Products Manufacturing & 45,4 & 45 & 734,7 & 722,8 \\
325 & Chemical Manufacturing & 15,6 & 14,7 & 114 & 107,5 \\
326 & Plastics and Rubber Products Manufacturing & 7,8 & 8,5 & 31,3 & 37,1 \\
327 & Nonmetallic Mineral Product Manufacturing & 13,4 & 9,2 & 89,6 & 54,3 \\
331 & Primary Metal Manufacturing & 22,1 & 21,5 & 180,6 & 176 \\
332 & Fabricated Metal Product Manufacturing & 3,6 & 3,9 & 9 & 10,4 \\
333 & Machinery Manufacturing & 13,3 & 15 & 72,7 & 90,9 \\
334 & Computer and Electronic Product Manufacturing & 17,3 & 10,8 & 136,6 & 71,5 \\
& Electrical Equipment, Appliance, and Component & & & & \\
335 & Manufacturing & 14,8 & 17,2 & 105,3 & 113,4 \\
336 & Transportation Equipment Manufacturing & 31,6 & 29 & 365 & 296,3 \\
337 & Furniture and Related Product Manufacturing & 11,0 & 12,6 & 61,5 & 73,5 \\
339 & Miscellaneous Manufacturing & 10,1 & 11,7 & 52,4 & 64,1 \\
\hline & $\quad \mathbf{1 8 , 4}$ & $\mathbf{1 8 , 5}$ & $\mathbf{1 7 8 , 6}$ & $\mathbf{1 7 5 , 1}$ \\
\hline
\end{tabular}

\section{Discussion and conclusion}

The study aimed to present the current state of the global PC industry and its market concentration. In its past, the PC market structure followed the classic U-pattern of a competitive phase, then followed by a consolidation period (Noam, 2009). Present results show that the PC industry is increasingly concentrating and show an oligopoly market structure which is an answer to RQ1. The results confirm a particular market power of PC vendors Lenovo, HP, Dell, Apple, Acer and Asus.

When interpreting the PC vendors' market power, the significance and specifics of national and regional markets should not be neglected, particularly the U.S. market, and the Chinese market which is the world's base for computers' production, but also the largest consumer of computer products (Ibis, 2019).

According to Krabeepetcharat (2012) (in Marley \& Mooney, 2014) the consolidation of computer manufacturers is expected to increase over the coming years as companies must continue to reduce production costs to remain competitive.

The CR indicators show a strong correlation with the companies' revenue for the period of 2017-2020 that indicate the importance of competitive activities PC companies are conducting to maintain the market share and power (RQ2). The profitability is determined by supply chain 
efficiency and supplementary products and services where large companies advantage in manufacturing efficiencies, significant marketing investments and sales channels while small companies compete by offering unique products or localized service (First research, 2020). The average PC selling price in recent years has been relatively constant (approx. 630 U.S. dollars) and it is expected to fall due to pricing trends of memory components (Alsop, 2020).

Answering RQ3 by comparing the concentration trends of the PC industry with the U.S. manufacturing industry led to the conclusion that both industries face a declining number of businesses. However, average concentration measures (CR4 and $\mathrm{HHI}$ ) in U.S. manufacturing sectors did not increase considerably as noted in the PC industry, which can be explained by the particularity of the PC industry as the hardware industry in always changing IT sector, influenced significantly by global trends.

Similar results are seen on the European market as well, where the average industry in 10 European economies recorded increase in 2-3 percentage points in the largest companies (Bajgar et al., 2019). Increase of in 4-8 percentage points in industry concentration is noted for the average industry (manufacturing and non-financial services) in Europe and North America according to the Orbis-Worldscope-Zephyr data, and it was not led by digitalintensive sectors (ibid).

The process of globalization contributed to the increase in market concentration in the world markets (Ginevičius \& Čirba, 2009). According to Pleatsikas \& Teece (2001) competition in the high technology industry is different than in more mature and stable industries as paradigm shifts may result in drastic changes in competitive positions. Moreover, the previously mentioned authors elaborated that monopoly power can be assessed through: 1) innovative activity (e.g. R\&D expenditures, product innovations), 2) competitive activity (e.g. change in customer purchases, changes in shares, potential entry) and 3) pricing responses and flexibility. If innovative activities are high, monopoly power is not likely to exist (ibid). High degree of concentration may not correspond to stable tight oligopoly in high tech as Ernst (1998) recognizes 3 sources of globalized high-tech industries: 1) fast capacity expansion due to extremely short product cycles, 2) complex supply chain that may lead to periodic shortages, 3) highly volatile demand patterns and innovations. Although part of the IT industry, the PC industry has high entry barriers and therefore its innovative activities (e.g. in terms of product/service cycles) are longer in comparison to the software part of the IT industry, or component manufacturers (e.g. microprocessors).

On the example of the U.S. equity market, Griffin (2018) reasons that globalization leads to the reallocation of market shares (higher concentration) within the industry by harming small firms only. Research on the market structure of the U.S. economy, in general, is scarce and dated (Abdel-Raouf, 2009). The author found that the U.S. manufacturing sector has become more competitive in 1997 and noted that international trade has a significant role in keeping the U.S. manufacturing industries competitive. International trade has more influence on electronic product manufacturing and transportation equipment manufacturing than the other subsectors (Abdel-Raouf, 2009) which also explains the results of this exploratory study in terms of $\mathrm{CR}$ and $\mathrm{HHI}$ values in PC vs. U.S. manufacturing industry.

The growing popularity of portable devices such as smartphones and tablets is negatively affecting computer sales, and more and more manufacturers are considering abandoning PC production (Marley \& Mooney, 2014). Although the market structure of the PC industry has oligopolistic characteristics, due to dynamic technological innovations not only in the PC industry but also in competitive industries such as the mobile phone industry or tablet industry, 
PC vendors enjoy less market power than manufacturers of some other more stable oligopolistic industries.

The rise of competition in the PC industry weakens the competition in the sense that companies that no longer can follow the economy of scale leave the industry, however competition in the industry is still dynamic between leading companies. The dynamics of the PC industry can be demonstrated in its envisioned future of 2-in-1 computers and in creating partnerships with innovative companies that develop new products and services that will expand the capabilities and life cycle of PCs, as expected from new technologies such as $5 \mathrm{G}$, artificial intelligence and others. Major PC manufacturers used their strong brands to expand horizontally to related product lines (Noam, 2009), for example, Lenovo bought Motorola smartphone business in 2014, and this trend is expected in the future as well.

The limitation of this study includes using single data measure (unit shipment) to define PC industry concentration, however, this measure has become a reporting standard and other measures for the PC industry are inaccessible to the scientific and general public as being part of market research reports. Only two concentration measures have been investigated in the study which is related to the limitation of available data as explained previously. In addition, revenue and net income for PC vendors have been calculated on the basis of totals generated from all markets (not only PC market, although it is predominant), as separate data was not publicly available. For example, Lenovo's PC revenue contributes to approx. $80 \%$ to the Group's total revenue (Lenovo, 2020).

Future research could cover the emerging trend of manufacture reshoring as "partial or total return of production previously offshored to low-wage countries to the original country, to serve local, regional or global demand" (Needham, 2013). The topic is increasingly discussed by practitioners, policymakers and scholars (Barbieri et al., 2017). The trend may influence the market power of PC manufacturers and should be investigated in more detail in the future.

The number of shipments clearly shows the increase in market concentration in the PC industry. During the five year period, the position of the four dominant companies has been strengthened, which is confirmed by both market concentration indicators used (CR and $\mathrm{HHI})$. However, research is needed to confirm if the PC industry is properly analysed and if more substitute products should be taken into the analysis, such as tablets.

\section{Acknowledgment}

This work has been supported by the Croatian Science Foundation [grant number UIP-201705-7625].

\section{References}

Abdel-Raouf, F. (2009). How Competitive is the US Manufacturing Sector? Eastern Economic Journal, 35, pp. 52-70. DOI: 10.1057/palgrave.eej.9050043

Adelaja, A., Menzo, J., \& McCay, B. (1998). Market Power, Industrial Organization and Tradeable Quotas. Review of Industrial Organization, 13, pp. 589-601. DOI:10.1023/A:1007799229046

Alsop, T. (2020). PCs: global ASP forecast 2015-2019. Available at: https://www.statista.com/statistics/722992/worldwide-personal-computers-average-selling-price/ (last accessed July 13, 2020)

Arora, A., Gambardella, A., \& Torrisi, S. (2001). In the Footsteps of Silicon Valley? Indian and Irish Software in the International Division of Labour. STANFORD Institute for Economic policy research. SIEPR Discussion Paper No. 00-41. Available at: file:///C:/Users/Ivana/AppData/Local/Temp/In the footsteps of Silicon Valley Indian and Iris. pdf (last accessed July, 12, 2020) 
Bajgar, M., Berlingieri, G., Calligaris, S., Criscuolo, C. and Timmis, J., "Industry Concentration in Europe and North America", OECD Productivity Working Papers, 2019-18, OECD Publishing, Paris. DOI: $10.1787 / 24139424$

Banovac, E. (2005). Measuring concentration in the energy markets. Nafta: exploration, production, processing, petrochemistry, 56 (6), pp. 249-256.

Barbieri, P., Ciabuschi, F., Fratocchi, L. \& Vignoli, M. (2017). Manufacturing reshoring explained: An interpretative framework of ten years of research. In Reshoring of Manufacturing: Drivers, Opportuniteis and Challenges (Alessandra Vecchi), Cham, Switzerland: Springer International Publishing. DOI:10.1007/978-3-319-58883-4_1

Bresnahan, T. F., \& Greenstein, S. (1999). Technological competition and the structure of the computer industry. The Journal of Industrial Economics, 47(1), pp. 1-40. DOI: 10.1111/1467-6451.00088

Carlson, P. E. (2006). Personal Computer Industry Trends. Regional Growth Strategies report. Available at: https://www.regionalgrowth.com/pubs/industrystudies/Personal Computer Industry Trends.pdf (last accessed January 10, 2021)

Chu, J. (2013). Quantifying nation equity with sales data: A structural approach. International Journal of Research in Marketing, Vol. 30, pp. 19-35. DOI: 10.1016/j.jijesmar.2012.06.005

Dedrick, J. \& Kraemer, K. L. (2002). Globalization of the Personal Computer Industry: Trends and Implications. Center for Research on Information Technology and Organizations (CRITO). University of California, Irvine. Available at: https://escholarship.org/content/at6wq2f4hx/qt6wq2f4hx.pdf?t=Inpatr (last accessed January 10, 2021)

Dedrick J. \& Kraemer, K. L. (2005). The impacts of IT on firm and industry structure: The personal computer industry. California Management Review, Vol. 47 (3), pp. 122-142. DOI: $10.2307 / 41166309$

Den Hartigh, E., Ortt, J. R., Kaa, G., Stolwijk, C. M. (2016). Platform control during battles for market dominance: The case of Apple versus IBM in the early personal computer industry. Technovation, Vol. 48-49, pp. 4-12. DOI: 10.1016/j.technovation.2015.12.001

Deng, P. (2009). Why do Chinese firms tend to acquire strategic assets in international expansion? Journal of World Business, Vol. 44, pp. 74-84. DOI: 10.1016/j.jwb.2008.03.014

Ernst, D. (1998). High-Tech competition puzzles - How globalization affects firm behavior and market structure in the electronics industry. Revue d'économie, 85, pp. 9-30. Available at: https://www.persee.fr/doc/rei 0154-3229 1998 num 8511722

Fare, R., Grosskopf, S. \& Tremblay, V. J. (2012). Market Power and Technology. Review of Industrial Organization, 40, pp. 139-146. DOI: 10.1007/s11151-012-9334-z

First Research (2020). Excerpt from Personal Computer Manufacturing Industry Profile. Available at: http://www.firstresearch.com/industry-research/Personal-Computer-Manufacturing.html (last accessed June 11, 2020)

Gartner (2017). Gartner Says 2016 Marked Fifth Consecutive Year of Worldwide PC Shipment Decline. Stamford, Conn., January 11, 2017. Available at:: https://www.gartner.com/en/newsroom/pressreleases/2017-01-11-gartner-says-2016-marked-fifth-consecutive-year-of-worldwide-pcshipment-decline (last accessed June 11, 2020)

Gartner (2018). Gartner Says Worldwide PC Shipments Declined 2 Percent in 4Q17 and 2.8 Percent for the Year. Stamford, Conn., January 11, 2018. Available at:: https://www.gartner.com/en/newsroom/press-releases/2018-01-11-gartner-says-worldwide-pcshipments-declined-2-percent-in-4q17-and-28-percent-for-the-year (last accessed June 11, 2020)

Gartner (2019). Gartner Says Worldwide PC Shipments Declined 4.3 Percent in 4Q18 and 1.3 Percent for the Year. Stamford, Conn., January 10, 2019. Available at:: 
https://www.gartner.com/en/newsroom/press-releases/2019-01-10-gartner-says-worldwide-pcshipments-declined-4-3-perc (last accessed June 11, 2020)

Gartner (2020). Gartner Says Worldwide PC Shipments Grew 2.3\% in 4Q19 and 0.6\% for the Year. Stamford, Conn., January 13, 2020. Available at:: https://www.gartner.com/en/newsroom/pressreleases/2020-01-13-gartner-says-worldwide-pc-shipments-grew-2-point-3-percent-in-4q19and-point-6-percent-for-the-year (last accessed June 11, 2020)

Gartner (2020)b. Gartner Says Worldwide PC Shipments Declined 12.3\% in the First Quarter of 2020 Due to Coronavirus Pandemic. Stamford, Conn., April 13, 2020. Available at: https://www.gartner.com/en/newsroom/press-releases/2020-04-13-gartner-says-worldwide-pcshipments-declined-12-point-3-percent-in-the-first-quarter-of-2020-due-to-coronaviruspandemic (last accessed June 11, 2020)

Gartner (2020)c. Gartner Says Worldwide PC Shipments Grew 2.8\% in the Second Quarter of 2020. Stamford, Conn., July 9, 2020. Available at: https://www.gartner.com/en/newsroom/pressreleases/2020-07-09-gartner-says-worldwide-pc-shipments-grew-2point8-percent-in-secondquarter-of-2020 (last accessed July 13, 2020)

Gartner (2021). Gartner Says Worldwide PC Shipments Grew 10.7\% in Fourth Quarter of 2020 and $4.8 \%$ for the Year. Stamford, Conn., January 11, 2021. Available at: https://www.gartner.com/en/newsroom/press-releases/2021-01-11-gartner-says-worldwide-pcshipments-grew-10-point-7-percent-in-the-fourth-quarter-of-2020-and-4-point-8-percent-for-theyear (last accessed February 8, 2021)

Ginevičius R. \& Čirba, S. (2009). Additive measurement of market concentration. Journal of Business Economics and Management, 10(3), pp. 191-198. DOI: 10.3846/1611-1699.2009.10.191-198

Griffin, T. P. (2018). Globalization and U.S. Industry Concentration. Available at: (last accessed June 11, 2020). DOI: $10.2139 /$ ssrn.3287328

IBIS world (2019) Computer Manufacturing in China industry trends (2015-2020). Available at: https://www.ibisworld.com/china/market-research-reports/computer-manufacturing-industry/ (last accessed January 10, 2021)

Lenovo official website. FY 2019/20 Annual results announcement. Available at: https://investor.lenovo.com/en/financial/results/announcement 1920 q4.pdf (last accessed February 22, 2021)

Lin, F. (2013), "Is there any paradox of Lerner index-based on the research of the market power of China civil aviation", Finance \& Economics, Vol. 8, pp. 53-58. DOI: 10.1108/IJCS-08-2017-0009

Macrotrends, (2021). Available at: https://www.macrotrends.net/stocks/charts/HPQ/hp/financialstatements (last accessed February 22, 2021)

Marley R., \& Mooney, J. L. (2014). M\&A: The Incredible Shrinking U.S. PC Industry. The Journal of Corporate Accounting \& Finance, Vol. 25(6). DOI: 10.1002/jcaf.21987

Mazzucato, M. (2002). The PC industry: New economy or early life-cycle? Review of Economic Dynamics, 5(2), pp. 318-345. DOI: 10.1006/redy.2002.0164

Naldi, M. \& Flamini, M. (2014). The CR4 index and the interval estimation of the Herfindahl-Hirschman Index: an empirical comparison. Available at: https://hal.archives-ouvertes.fr/hal-01008144 (last accessed June 11, 2020). DOI: 10.2139/ssrn.2448656

Needham, C. (2013). Reshoring of EU manufacturing. European Parliamentary Research Service, 140791REV1. Available at: https://www.europarl.europa.eu/EPRS/140791REV1-Reshoring-ofEU-manufacturing-FINAL.pdf (last accessed June 15, 2020)

Noam, E. M. (2009). Media Ownership and Concentration in America. Oxford University Press. DOI: 10.1093/acprof:oso/9780195188523.001.0001

Özsomer, A., \& Cavusgil, S. T. (2000). The effects of technology standards on the structure of the global PC industry. European Journal of Marketing. DOI: 10.1108/03090560010342601 
Pavić, I., Benić, Đ. \& Hashi, I. (2009). Mikroekonomija, 3. ed. Split: Sveučilište u Splitu (University of Split), Ekonomski fakultet (Faculty of Economics).

Pavić, I., Galetić, F. \& Piplica, D. (2016). Similarities and Differences between the CR and HHI as an Indicator of Market Concentration and Market Power. British Journal of Economics, Management \& Trade, 13(1), pp. 1-8. DOI: 10.9734/BJEMT/2016/23193

Pleatsikas, C. \& Teece, D. (2001). The analysis of market definition and market power in context of rapid innovation. International Journal of Industrial Organization, 19, pp. 665-693. DOI: 10.1016/S0167-7187(00)00088-6

Richter, F. (2019). PC Market Shrinks For the Seventh Consecutive Year. Available at: https://www.statista.com/chart/12578/global-pc-shipments/ (last accessed July 13, 2020)

Stazhkova, P., Kotcofana, T., \& Protasov, A. (2017). Concentration indices in analysis of competitive environment: case of Russian banking sector. CBU International Conference Proceedings: Innovations in science and education, Prague, Czech Republic, Vol. 5. DOI:10.12955/cbup.v5.966

St. Thomas University. Econ 332: Industrial Organization: Concentration Ratio \& Other Industry Dana. Available at: https://libguides.stthomas.edu/c.php?g=88919\&p=571233 (last accessed June 11, 2020)

Sun, B., Jing W., Zhao, X. \& He Y. (2017). Research on market power and market structure. A direct measure of market power of internet platform enterprises. International Journal of Crowd Science, 1 (3), pp. 210-222. DOI: 10.1108/IJCS-08-2017-0009

Tipurić, D., Kolaković, M. \& Dumičić, K. (2003). Koncentracijske promjene hrvatske bankarske industrije u desetogodišnjem razdoblju (1993.-2002.). Zbornik Ekonomskog fakulteta u Zagrebu, 1 (1), pp. $1-22$.

US Census Bureau (2012). Concentration 2012. Available at: www.census.gov (last accessed May, 20, 2020)

US Census Bureau (2017). Number of Firms, Number of Establishments, Employment, Annual Payroll, and Preliminary Receipts by Enterprise Employment Size for the United States, All Industries: 2017. Available at: www.census.gov (last accessed May 20, 2020.)

Williams, W. \& Kallender, P. (2004). China's Lenovo to buy IBM's PC business.

US Department of Justice and the Federal Trade Commission, Horizontal Merger Guidelines, Available at: https://www.justice.gov/atr/horizontal-merger-guidelines-08192010\#5c (last accessed February 10, 2021)

InfoWorld. Available at: http://www.infoworld.com/t/hardware/chinas-lenovo-buyibms-pc-business-29 (last accessed May 12, 2020.)

Yaşar, M. \& Kiracı, K. (2017). Market Share, the Number of Competitors and Concentration: An Empirical Application on the Airline Industry. V. Anadolu International Conference in Economics, May 11-13, 2017, Eskişehir, Turkey. Available at: https://www.researchgate.net/publication/317400734 Market Share the Number of Competit ors and Concentration An Empirical Application on the Airline Industry (last accessed July 12, 2020). 